\title{
Utilization of vitamins in the production of cucumber seedlings under saline stress
}

Aécio Busch, Gabriela Moura Serafim, Julia Cabreira Carraro, Rafael Reverendo Vidal Kawano Nagamine, Murillo Ribeiro Freitas, Eduardo Pradi Vendruscolo

Universidade Estadual do Mato Grosso do Sul - UEMS. MS. E-mail: agrovendruscolo@gmail.com

\begin{abstract}
Numerous factors lead to the use of water with saline levels above those suitable for plant development, resulting in negative consequences on crops. Studies have sought techniques that aim to mitigate such consequences and the use of vitamins is promising, since these compounds improve the development conditions of vegetables. Thus, the study aimed to verify the ability of vitamins to mitigate the deleterious effects of using saline water, applied via irrigation during the formation of cucumber seedlings. Cucumber seeds were subjected to imbibition in three vitamin solutions $\left(100 \mathrm{mg} \mathrm{L}^{-1}\right.$ thiamine; $100 \mathrm{mg} \mathrm{L}^{-1}$ niacin; $50 \mathrm{mg}$ $\mathrm{L}^{-1}$ thiamine $+50 \mathrm{mg} \mathrm{L}^{-1}$ niacin), in addition to two controls, both with water imbibition. After sowing, irrigation was carried out with saline water $(100 \mathrm{mM} \mathrm{NaCl})$, for all treatments, except for one of the controls. It was found that irrigation with saline water affected all variables studied, without, however, having a positive effect from the application of vitamins. Thus, it was concluded that the vitamins were not able to mitigate the deleterious effects caused by the application of saline water under the conditions in which the study was carried out and that future studies should be carried out to evaluate different concentrations and forms of application of the vitamins.
\end{abstract}

Keywords: abiotic stress; seedling production; osmoregulation; Cucumis sativus L.

\section{Utilização de vitaminas na produção de mudas de pepineiro sob estresse salino}

\section{Resumo}

Inúmeros fatores levam à utilização de água com teores salinos acima daqueles adequados ao desenvolvimento vegetal, acarretando consequências negativas sobre os cultivos. Estudos têm buscado técnicas que visem amenizar tais consequências e a utilização de vitaminas é promissora, uma vez que esses compostos melhoram as condições de desenvolvimento dos vegetais. Assim, o estudo teve como objetivo verificar a capacidade das vitaminas em mitigar os efeitos deletérios da utilização de água salina, aplicada via irrigação durante a formação de mudas de pepino. Sementes de pepineiro foram submetidas à embebição em três soluções vitamínicas (100 mg L tiamina; $100 \mathrm{mg} \mathrm{L}^{-1}$ niacina; $50 \mathrm{mg} \mathrm{L}^{-1}$ tiamina $+50 \mathrm{mg}$ $\mathrm{L}^{-1}$ niacina), além dois controles, ambos com embebição em água. Após a semeadura a irrigação foi realizada com água salina (100 $\mathrm{mM}$ de $\mathrm{NaCl})$, para todos os tratamentos, com exceção de um dos controles. Verificou-se que a irrigação com água salina afetou todas as variáveis estudas, sem que, no entanto, houvesse efeito positivo da aplicação das vitaminas. Dessa maneira, concluiu-se que as vitaminas não foram capazes de mitigar os efeitos deletérios causados pela aplicação de água salina nas condições em que o estudo foi realizado e que estudos futuros devem ser realizados para avaliar diferentes concentrações e formas de aplicação das vitaminas.

Palavras-Chave: estresse abiótico; produção de mudas; osmorregulação; Cucumis sativus L.

\section{Introduction}

Among all the stages of development of a plant, salinity interferes negatively in all, being more severe in germination, emergence and initial growth, in most agricultural crops (ARAUJO et al., 2016). The accumulation of salts affects the functioning of the root by reducing the osmotic potential, causing an ionic imbalance in the soil, which reduces the absorption of some essential mineral nutrients, these changes are variable 
between species and between cultivars, and may be more severe or not (MEDEIROS et al., 2007; BRITO et al., 2014; ARAUJO et al., 2016).

We can also highlight that salinity becomes a serious obstacle to the production system, both due to changes in the physical and chemical aspects of the soil, as well as by the action of some specific ions on the germination, growth, production and nutrition of plants (CAVALCANTE et al., 2010; BEZERRA et al., 2016). Ahmed and Montani (2010) and Bezerra et al. (2016) report, in this same context, that the most notable consequences of salinity on plants are related to changes in osmotic potential, ionic toxicity and imbalance in the absorption of nutrients, consequently reducing their growth and production.

Briefly, the effect of salinity on plant growth is due to the increase in osmotic pressure of the soil or substrate, which as a reflex acts negatively on physiological processes, decreasing water absorption by the roots, preventing meristematic activity and cell stretching (LIMA et al., 2015). It also causes morphophysiological changes, such as nutritional imbalance, reduction in stomatal conductance and lower proportions in the rates of transpiration, photosynthesis and internal $\mathrm{CO}_{2}$ concentration in the leaves, resulting morphologically in the reduction of biomass in the plant and in fruit yield (BOSCO et al., 2009; LIMA et al., 2015).

Albuquerque et al. (2016) observed an influence of salinity in terms of emergence, growth and dry mass accumulation in different cucumber cultivars. According to him, the influence on the emergence of seedlings may have happened by reducing the ability to imbibe the seed, due to the increase in the osmotic potential of the cultivation medium, preventing or delaying germination, and consequently the emergence of seedlings. The influence on growth, on the other hand, may be related to the high concentrations of sodium salts that interact negatively in the physiology of plants by promoting ionic, osmotic and nutritional interactions that are harmful to plants. As for the accumulation of dry mass, the influence is given to the increase in the electrical conductivity of the water, to the nutritional imbalance and toxicity, which result in loss of breath, root expansion, water absorption and $\mathrm{CO}_{2}$ fixation, thus reducing the total dry mass.

Techniques and products to alleviate the deleterious effects of abiotic stresses have been studied due to the large number of factors that exert some type of influence on cultures of economic interest. In this context, the exogenous application of vitamins has been studied as a stress-relieving technique caused by both biotic and abiotic factors (ABDALLAH et al., 2016). The use of vitamins can also improve physiological conditions, since it provides an increase in energy (EL-BASSIOUNY, 2005) and nutritional reserves, essential for the correct development of plant organs (TAIZ et al., 2017).

In a study developed with the application of vitamin in the culture of wheat, the immersion of the seeds in thiamine solution, provided the absorption and accumulation of nutrients, improving the development and increasing the productivity of the plants cultivated in fertilized soil with half of the fertilization recommendation. (EL-BASSIOUNY et al., 2014). For corn cultivars subjected to salt stress, the use of thiamine via seed immersion or via foliar application increased the levels of N, P, $\mathrm{Ca}$ and $\mathrm{K}$ in the tissues of plant organs (KAYA et al., 2015). The increase in biometric and productive characteristics was also obtained with the application of niacin to the cultures of quinoa, when the leaf application was performed (Abdallah et al., 2016) and for sweet corn and beans when the application was made via seed treatment (VENDRUSCOLO et al., 2018; VENDRUSCOLO; SELEGUINI, 2020).

Thus, the study aimed to verify the ability of vitamins to mitigate the deleterious effects of using saline water, applied via irrigation during the formation of cucumber seedlings.

\section{Material and Methods}

The work was developed in an agricultural screen environment with black monofilament screen with $30 \%$ shading, in the experimental area of the State University of Mato Grosso do Sul (UEMS), University Unit of Cassilândia (UUC), between the months of August to November 2019.

Prior to the implementation of the experiment, of Cucumis sativus seeds (cv. Esmeralda) were soaked in four solutions (100 $\mathrm{mg} \mathrm{L}^{-1}$ thiamine solution; $100 \mathrm{mg} \mathrm{L}^{-1}$ niacin solution; $50 \mathrm{mg} \mathrm{L}^{-1}$ thiamine $+50 \mathrm{mg} \mathrm{L}^{-1}$ niacin solution), in addition to distilled water, for $24 \mathrm{~h}$, in a growth room with controlled temperature $\left(25 \pm 0.5^{\circ} \mathrm{C}\right)$.

After the imbibition period, sowing was carried out, depositing one seed per cell in 
expanded polystyrene trays, with 128 cells, filled with commercial organic substrate. The trays with the seeds were distributed on a metal bench inside the cultivation environment, composing the experiment in a completely randomized design, with five replications. The five treatments consisted of the aforementioned imbibition solutions and irrigation with saline water (100 $\mathrm{mM} \mathrm{NaCl}$ ), in addition to a control treatment, with seed soaking in distilled water and irrigation with fresh water. Each repetition was composed of 5 plants. The irrigations were carried out daily, in sufficient quantity to moisten the substrate, but without excessive drainage at the bottom of the trays.

At 16 days after seedling emergence, measurements were made of the shoot length $(\mathrm{SL})$ and root length (RL), stem diameter (SD), leaf area (LA) and number of leaves (NL). It was also evaluated the shoot dry mass (SDM) and root dry mass (RDM): the materials obtained were inserted in paper bags and kept in an oven at 65 ${ }^{\circ} \mathrm{C}$, with forced air circulation, until a constant mass was obtained. Dickson's quality index (DQI) was also obtained, determined by: $\mathrm{DQI}=$ (SDM+RDM) / (SL / SD + SDM / RDM) (DICKSON et al., 1960).

Data were subjected to analysis of variance ( $\mathrm{F}$ test) and the averages were compared by the LSD test, at $5 \%$ probability. The analyzes were performed using the statistical software Sisvar $^{\circledR} 5.6$ version for Windows (FERREIRA, 2014).

\section{Results and Discussion}

The deleterious effect of irrigation with saline water was verified, even when the seeds were subjected to soaking in vitamin solution, on the variables of shoot and root length, shoot and root dry mass and Dickson's quality index, however there was no significance between the treatments composed by the application of saline water and the control for the diameter of the stem (Figure 1).

Figure 1. Shoot length (A), root length (B), shoot dry mass (C), root dry mass (D), stem diameter (E) and Dickson quality index (F) of cucumber seedlings treated with vitamins and irrigated with saline water.
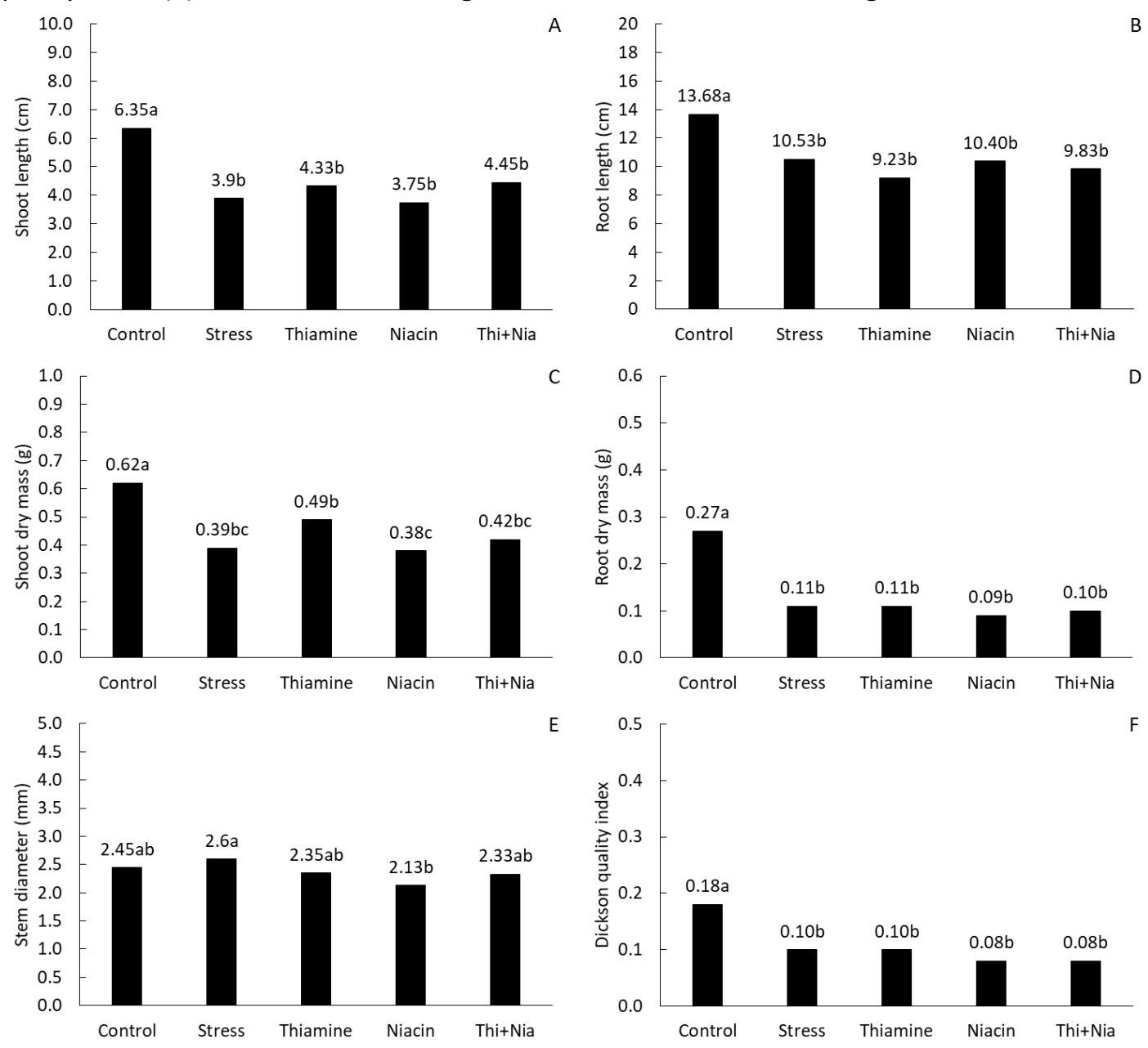
For the number of leaves, there was a significant difference between the control treatment and the treatment composed only by the application of saline water, with no difference for the treatments in which the vitamins were used (Figure 2A). This result demonstrates the potential of vitamins in mitigating the deleterious effects of irrigation with saline water, corroborating the results obtained by Vendruscolo and Seleguini (2020), who studied similar treatments with the culture of sweet corn. In this study, the authors found that the treatment of seeds, by soaking in solutions composed of $100 \mathrm{mg} \mathrm{L}^{-1}$ of niacin, $100 \mathrm{mg} \mathrm{L}^{-1}$ of thiamine and the combination of $50 \mathrm{mg} \mathrm{L}^{-1}$ of niacin and $50 \mathrm{mg} \mathrm{L}^{-1}$ of thiamine, reduced the total dry matter losses of the plants by about $20 \%, 55 \%$ and $85 \%$, respectively, in relation to the control treatment with saline water.

Figure 2. Number of leaves (A) and leaf area (B) of cucumber seedlings treated with vitamins and irrigated with saline water.

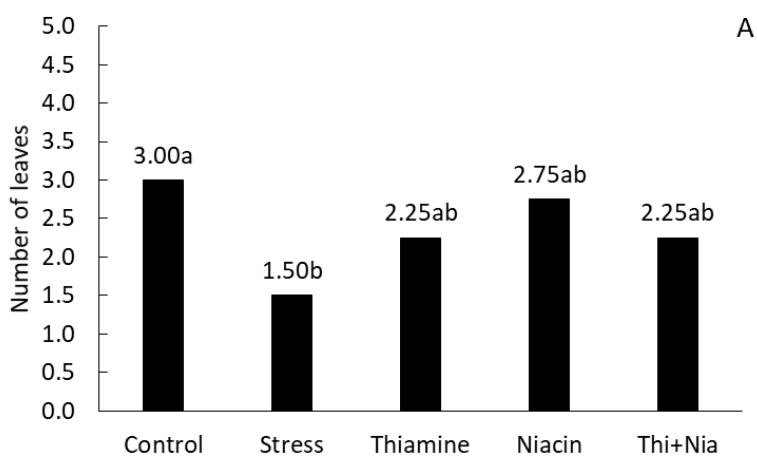

Different from what was observed for the number of leaves, the treatments with vitamins did not provide increments in leaf area, not differing from the treatment composed only by irrigation with saline water (Figure 2B). This indicates that the vitamins provided a greater leaf emission, but without influencing the development of the limbus. This may be related to the form of irrigation, in which water containing a high concentration of salts had direct contact with the leaves.

The effects caused by the accumulation of salts, both in the plant and in the substrate, affect all the organs of the plants. In this sense, high concentrations of $\mathrm{Na}^{+}$in the substrate, result in less capacity of the plants to carry out the absorption of water and nutrients, in addition to hindering their translocation internally, from the root to the crown (ADIKU et al., 2001; PORCEL et al., 2012). In addition, when accumulated in plant organs in high concentrations, $\mathrm{Na}^{+}$becomes toxic, decreasing photosynthetic capacity and intensifying the occurrence of oxidative stress (ACOSTA-MOTOS et al., 2017; MORAIS et al., 2018).

In the present study, the action of concentration of salts may have been further leveraged by the form of application, since the

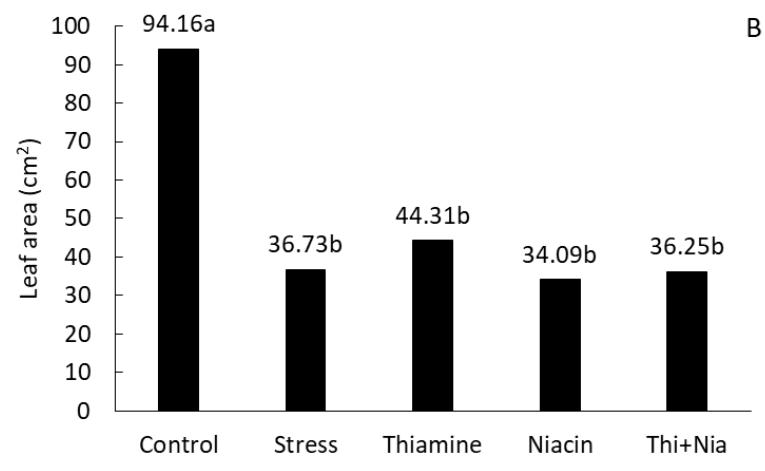

irrigation was carried out in such a way that the solution reached the aerial organs of the plant, simulating a sprinkler system. Thus, after the evaporation of excess water, the deposition of the salts occurred directly on the epidermis of the leaves and stem, accentuating the effect of osmosis and even causing injuries to the tissues. With this situation in mind, stress potentiation was evident, culminating in different results from those observed in other studies, in which the effects of salinity and other abiotic factors were reduced with the application of vitamins.

For the culture of corn, it was verified that the soaking of seeds in solution containing up to $150 \mathrm{mg} \mathrm{L}^{-1}$ thiamine resulted in better seedling development and an increase of up to $50 \%$ in the emergence speed, when they were submitted to salinity (KAYA et al., 2015). Also, the application of thiamine solution, in concentrations of 50 and $100 \mathrm{mg} \mathrm{L}^{-1}$, resulted in easing the stresses caused by the lack of water in upland rice plants, increasing panicle length and fertility (VENDRUSCOLO et al., 2020).

Other studies also point to the potential use of vitamins, even in conditions where there are no apparent stresses or being applied on purpose. In this context, the application of thiamine and niacin, alone and together, 
increased the biometric and fertility characteristics of upland rice plants (VENDRUSCOLO et al., 2019). In addition, for vegetable species the application of these vitamins was also effective for increasing the development of mustard plants (VENDRUSCOLO et al., 2017b) and melon seedlings (VENDRUSCOLO et al., 2017a), acting as a biostimulant.

The effects related to the application of vitamins are mainly protective, in which vitamins play the role of activating secondary metabolism (VENDRUSCOLO et al., 2019). In this context, thiamine acts on carbon metabolism, protein synthesis and has a protective effect against the effects caused by biotic and abiotic stresses, also playing a coenzyme role in different metabolic pathways of vegetables (GOYER, 2010; KAYA et al., 2015). In addition, niacin has a biostimulating action (VENDRUSCOLO et al., 2018), in which it stimulates the accumulation of energy and nutritional reserves in plants, so that they acquire better conditions to go through periods of stress (EL-BASSIOUNY et al., 2014; TAIZ et al., 2017).

\section{Conclusion}

The vitamins were unable to mitigate the deleterious effects caused by the application of saline water under the conditions in which the study was conducted.

\section{References}

ABDALLAH, M. M. S.; EL HABBASHA, S. F.; EL SEBAI, T. Comparison of yeast extract and Nicotinaminde foliar applications effect on quinoa plants grown under sandy soil condition. International Journal of PharmTech Research, v.9, n.7, 2016.

AHMED, B. A. O.; INOUE, M.; MORITANI, S. Effect of saline water irrigation and manure application on the available water content, soil salinity, and growth of wheat. Agricultural water management, v.97, n.1, p.165-170, 2010. https://doi.org/10.1016/j.agwat.2009.09.001

ALBUQUERQUE, J. R. T.; DA SILVA SÁ, F. V.; OLIVEIRA, F. A.; PAIVA, E. P.; ARAÚJO, E. B. G.; SOUTO, L. S. Crescimento inicial e tolerância de cultivares de pepino sob estresse salino. Revista Brasileira de Agricultura Irrigada-RBAI, v.10, n.2, p.486-495, 2016. https://doi.org/10.7127/rbai.v10n200355
ARAUJO, E. B. G.; SÁ, F. V. D. S.; OLIVEIRA, F. A. D.; SOUTO, L. S.; PAIVA, E. P. D.; SILVA, M. K. D. N.; BRITO, M. E. B. Crescimento inicial e tolerância de cultivares de meloeiro à salinidade da água. Revista Ambiente \& Água, v.11, n.2, p.462471, 2016. https://doi.org/10.4136/ambiagua.1726

ACOSTA-MOTOS, J. R.; ORTUÑO, M. F.; BERNALVICENTE, A.; DIAZ-VIVANCOS, P.; SANCHEZBLANCO, M. J.; HERNANDEZ J. A. Plant responses to salt stress: adaptive mechanisms. Agronomy. v.7, p.1-18, 2017. https://doi.org/10.3390/agronomy7010018

ADIKU, S. G. K.; RENGER, M.; WESSOLEK, G.; FACKLAM, M.; HECHT-BUCHOLTZ, C. Simulation of the dry matter production and seed yield of common beans under varying soil water and salinity conditions. Agricultural Water Management, v.47, p.55-68, 2001. https://doi.org/10.1016/S0378-3774(00)00094-9

BEZERRA, J. D.; PEREIRA, W. E.; SILVA, J. M. D.; RAPOSO, R. W. C. Crescimento de dois genótipos de maracujazeiro-amarelo sob condições de salinidade. Revista Ceres, v.63, n.4, p.502-508, 2016. https://doi.org/10.1590/0034-

\section{X201663040010}

BRITO, M. E. B.; FERNANDES, P. D.; GHEYI, H. R.; MELO, A. S.; SOARES FILHO, W. S.; SANTOS, R. T. Sensibilidade à salinidade de híbridos trifoliados e outros porta-enxertos de citros. Revista Caatinga, v.27, p.17-27, 2014.

CAVALCANTE, L. F.; VIEIRA, M. D. S.; SANTOS, A. F. D.; OLIVEIRA, W. M. D.; NASCIMENTO, J. A. M. D. Água salina e esterco bovino líquido na formação de mudas de goiabeira cultivar Paluma. Revista Brasileira de Fruticultura, v.32, n.1, p.251-261, $2010 . \quad$ https://doi.org/10.1590/S010029452010005000037

EL-BASSIOUNY, H. M. S. Physiological responses of wheat to salinity alleviation by nicotinamide and tryptophan. International Journal of Agriculture and Biology, v.7, n.4, p.653-659, 2005.

EL-BASSIOUNY, H. S. M.; BAKRY, B. A.; ATTIA, A. A. E. M.; ABD ALLAH, M. M. Physiological role of humic acid and nicotinamide on improving plant growth, yield, and mineral nutrient of wheat 
(Triticum durum) grown under newly reclaimed sandy soil. Agricultural Sciences, v.5, p.687-700, 2014. http://dx.doi.org/10.4236/as.2014.58072

FERREIRA, D. F. Sisvar: a Guide for its Boots rap procedures in multiple comparisons. Ciência e Agro tecnologia, v.38, n.2, p.109-112, 2014. http://dx.doi.org/10.1590/S1413$\underline{70542014000200001}$

GOYER, A. Thiamine in plants: aspects of its metabolism and functions. Phytochemistry, v. 71, n.14-15, p.1615-1624, 2010. https://doi.org/10.1016/j.phytochem.2010.06.02 $\underline{2}$

KAYA, C.; ASHRAF, M.; SONMEZ, O.; TUNA, A. L.; POLAT, T.; AYDEMIR, S. Exogenous application of thiamin promotes growth and antioxidative defense system at initial phases of development in salt-stressed plants of two maize cultivars differing in salinity tolerance. Acta Physiologiae Plantarum, v.37, n.1, p.1741, 2015. https://doi.org/10.1007/s11738-014-1741-3

LIMA, L. A.; OLIVEIRA, F. D. A.; ALVES, R. C.; LINHARES, P. S. F.; MEDEIROS, A. M. A.; BEZERRA, F. M. S. Tolerância da berinjela à salinidade da água de irrigação. Revista agro@ mbiente online, v.9, n.1, p.27-34, 2015. http://dx.doi.org/10.18227/1982-

\section{0ragro.v9i1.2202}

MEDEIROS, J. F.; SILVA, M. C. C.; SARMENTO, D. H. A.; BARROS, A. D. Crescimento do meloeiro cultivado sob diferentes níveis de salinidade, com e sem cobertura do solo. Revista Brasileira de Engenharia Agrícola e Ambiental, v.11, n.3, p.248-255, 2007. https://doi.org/10.1590/S141543662007000300002

MORAIS, P. L. D. D.; DIAS, N. D. S.; OLIVEIRA, A. M. D.; SOUSA NETO, O. N. D.; SARMENTO, J. D. A.; GONZAGA, M. I. S. Effects of nutrient solution salinity on the physiological performance of melon cultivated in coconut fiber. Revista Caatinga, v.31, n.3, p.713-718, 2018. https://doi.org/10.1590/1983-

21252018v31n321rc

PORCEL, R.; AROCA, R.; RUIZ-LOZANO, J. M. Salinity stress alleviation using arbuscular mycorrhizal fungi. A review. Agronomy for
Sustainable Development, v.32, p.181-200, 2012. https://doi.org/10.1007/s13593-011-0029-x

TAIZ, L.; ZEIGER, E.; MOLLER, L. M.; MURPHY, A. Fisiologia e desenvolvimento vegetal. 6. ed. Porto Alegre: Artmed, 2017.

VENDRUSCOLO, E. P.; MARTINS, A. P. B.; SELEGUINI, A. Doses e parcelamento de niacina no desenvolvimento inicial de meloeiro Cantaloupe. Revista agro@mbiente on-line,v.11, n.3, p.209-214, 2017a.

http://dx.doi.org/10.18227/19828470ragro.v11i3.4009

VENDRUSCOLO, E. P.; OLIVEIRA, P. R.; SELEGUINI, A. Aplicação de niacina ou tiamina promovem incremento no desenvolvimento de mostarda. Revista Cultura Agronômica, v.26, n.3, p.433442, 2017b. https://doi.org/10.32929/24468355.2017v26n3p433-442

VENDRUSCOLO, E. P.; RODRIGUES, A. H. A.; MARTINS, A. P. B.; CAMPOS, L. F. C.; SELEGUINI, A. Tratamento de sementes com niacina ou tiamina promove o desenvolvimento e a produtividade do feijoeiro. Revista de Ciências Agroveterinárias, v.17, n.1, p.83-90, 2018. https://doi.org/10.5965/223811711712018083

VENDRUSCOLO, E. P.; RODRIGUES, A. H. A.; OLIVEIRA, P. R.; LEITÃO, R. A.; CAMPOS, L. F. C.; SELEGUINI, A.; LIMA, S. F. Exogenous application of thiamine on upland rice summited to water déficit. Revista de Ciências Agroveterinárias, v.19, n.1, p.48-53, 2020. https://doi.org/10.5965/223811711912020048

VENDRUSCOLO, E. P.; RODRIGUES, A. H. A.; OLIVEIRA, P. R.; LEITÃO, R. A.; CAMPOS, L. F. C.; SELEGUINI, A.; LIMA, S. F. Exogenous application of vitamins in upland rice. Revista de Agricultura Neotropical, v.6, n.2, p.1-6, 2019. https://doi.org/10.32404/rean.v6i2.3241

VENDRUSCOLO, E. P.; SELEGUINI, A. Effects of vitamin pre-sowing treatment on sweet maize seedlings irrigated with saline water. Acta Agronómica, v.69, n.1, p.20-25, 2020. https://doi.org/10.15446/acag.v68n4.67528 